ANDRZEJ K. LINK-LENCZOWSKI

Uniwersytet Jagielloński

iD ORCID ID: 0000-0002-7845-6783
WŁADZA I POLITYKA

W CZASACH NOWOŻYTNYCH

DYPLOMACJA I SPRAWY WEWNĘTRZNE

\title{
Oświecenie raz jeszcze
}

\author{
Enlightenment once more
}

$\Gamma$

ruizmem jest stwierdzenie, wpajane jeszcze niekiedy studentom, że współczesna cywilizacja euroatlantycka wywodzi się z Oświecenia i niesie istotny przekaz, powiązany przede wszystkim z ideami wolności i równości. Siłą rzeczy i z „dydaktycznej” konieczności przekaz ten jest uproszczony i nie zawsze pozwala zrozumieć przeszłość jako jeden z kluczy do prób „oswojenia” teraźniejszości, będącej zespołem zjawisk mocno uwarunkowanych rzeczywistością społeczną, polityczną, gospodarczą czy kulturalną, która nas otacza. Owa rzeczywistość, postrzegana jako zbiór zasad i prawd odnoszących się do kwestii szczegółowych, bywa (w pewnych okolicznościach, wynikających z właściwości oraz „klimatu” ideowego i społecznego danej epoki) w odmienny sposób i przez różne środowiska intelektualne (a także polityków) kontestowana. Siła tej kontestacji jest rozmaita. Będąc humanistami, w przeciwieństwie do przedstawicieli nauk podstawowych, nie potrafimy często udzielić klarownej odpowiedzi na najprostsze zdawałoby się pytania. Obraz, który przywołujemy, jest nieostry, o „rozmazanym” konturze. Chcemy „przebić się” ku przeszłości, by ją zrozumieć i przekazać jej kształt, ale często jesteśmy bezradni, a chęć precyzyjnego przedstawienia swego stanowiska zdaje się umykać naszemu intelektowi i dążeniu do opisu zjawisk w ich wszechstronnej złożoności. Pytania: skąd przychodzimy, w jakim momencie jesteśmy, dokąd i po co idziemy? - pytania, które humaniści zadają sobie często - albo pozostają bez odpowiedzi, albo nie jest ona na miarę naszych oczekiwań. Tak jest właśnie z Oświeceniem, które wprawdzie po tysiąckroć oswajane w naukowym czy popularnym dyskursie, wymyka się ocenom pozwalającym lepiej zrozumieć świat.

Jak zatem „odkurzyć” tę epokę, przybliżyć ją na nowo, pokazać jej współczesne znaczenie? Jest to tym ważniejsze, że w toku rozmaitych konfliktów politycznych i ideowych strony sporu, a raczej jedna ze stron, przywołują Oświecenie jako zjawisko negatywne, 
prowadzące do zniewolenia człowieka i wikłania go w dyskusje, które albo dawno rozstrzygnięto, albo są nie do rozstrzygnięcia, bo odwołują się do transcendencji, pozostając poza domeną wiedzy. Jesteśmy więc obecnie w poznawczym klinczu, ponieważ strony konfliktu tkwią na swych pozycjach, a przywoływanie dawno zużytych klisz, w rodzaju określenia „cywilizacja śmierci”, którym szermują niektórzy (bo nie wszyscy) teologowie i antropolodzy kultury, głównie katoliccy, utożsamiający się z nurtami i postaciami krytykującymi Oświecenie - najszerzej mówiąc konserwatywnymi czy ultrakonserwatywnymi - nie pokazuje żadnych pozytywnych rozwiązań poznawczych.

Wróćmy przeto do genezy Oświecenia. Mamy tu do czynienia z pewnym niedopowiedzeniem wynikającym ze skrótowości ujęć służących głównie celom dydaktycznym, przypisującym przesadnie dużą rolę Oświeceniu francuskiemu. Jest to słuszne w odniesieniu do drugiej połowy XVIII w. i w opisie mechanizmów upowszechniania zdobyczy dojrzałego Oświecenia - wolności, równości, tolerancji, autonomii jednostki szukającej miejsca w otwartym świecie.

Gdzie i kiedy rodziły się intelektualne oraz religijne przesłanki postaw, nazwanych później „oświeceniowymi”? Jaka była geneza tego zjawiska? W literaturze było ono wielokrotnie opisywane, ale chyba nie do końca jasno i bez uwzględnienia pewnej ciągłości postaw. Podwaliny myśli „swobodnie poszukującej” tkwią na Wyspach Brytyjskich i w Niderlandach, w postawach ludzi reprezentujących ideologię, myśl i teologię kalwinizmu, zresztą nie tylko radykalnego. Są widoczne w pismach religijnych radykałów na długo przed „sławetną rewolucją” 1688 r., zapowiadającą niejako dzieła uznanych później luminarzy wczesnego Oświecenia nurtu angielsko-szkockiego - Johna Locke’a czy Johna Tolanda. Wiązało się to z początkami tolerancji religijnej ${ }^{1}$ w Anglii i innego niż dotąd podejścia do nauki i postępu, gdyż coraz częściej zaczęto wyjaśniać różne zjawiska drogą analizy przyczyn naturalnych, nie zaś nadnaturalnych. Prace teologów i radykalnych kaznodziejów (ten element ich działalności jest bardzo ważny) otwierały wielu ludziom, nawet niewykształconym czy niepiśmiennym, oczy na nowość, zmianę, choćby doświadczaną intuicyjnie. W XVII w. ludzie prości, szukając wytłumaczenia mechanizmów funkcjonowania otaczającego ich świata, pełnego nowych bodźców, czego skutkiem był przyspieszony upływ czasu, zaczynali inaczej odbierać znaną im rzeczywistość. Był to proces powolny, pełen zakrętów i niepewności².

Kalwinizm odrzucił doktrynę biernego posłuszeństwa wobec ustanowionej przez Boga władzy. Teorie purytańskie odwoływały się do siły ludzkiej woli i w pewnym

${ }^{1}$ Por. choćby monografię J. Basisty, Anglia, świat i gwiazdy, Kraków 1994, gdzie autor ukazuje żywotność średniowiecznego pojmowania świata.

2 Ch. Hill, Oliver Cromwell, Warszawa 1988, s. 213, 228, passim; Wiek osiemnasty - wiek Oświecenia, rozdz. X (Kryzys świadomości europejskiej), Kolekcja „Gazety Wyborczej”, Mediasat Poland 2007, s. 197 i n., szczególnie s. 204; B. Coward, P. Gaunt, Stuartowie. Anglia 1603-1714, Kraków 2020, s. 772 i n. 
stopniu do ludzkiego rozumu, a nie do arbitralnej interwencji boskiej przychodzącej z zewnątrz. Działo się to w okresie, gdy na Wyspach Brytyjskich nie było jeszcze rozwiniętego przemysłu, w czasach, w których człowiek nie wykazał jeszcze w pełni, że potrafi narzucać swoją wolę otoczeniu, kiedy jedynie Sir Francis Bacon marzył, że nauka może dać ludziom do ręki władzę nad światem i w ten sposób „pokonać niedostatek”. Niewielu też pisarzy kwestionowało, podobnie jak Bacon i George Hakewill, wyższość starożytnej przeszłości nad teraźniejszością i przekonanie o „postępującym rozkładzie kultury ludzkiej”. Zaufanie do człowieka i jego możliwości mogło się kształtować jedynie stopniowo. W takim klimacie intelektualnym, zdaniem Christophera Hilla, można było

jedynie powoli i stopniowo umacniać zaufanie do człowieka: działalność na rzecz Boga była niezbędną koncepcją przejściową pomiędzy biernym posłuszeństwem wobec nieznoszącej oporu Opatrzności (dającej się łagodzić jedynie magią) a czynną walką o poprawę kondycji ludzkiej3.

Tak (choć nie jedynie) można było tłumaczyć powolność zmian w ludzkiej świadomości, drążących twardą jeszcze skorupę mentalności średniowiecznej. Wiek XVII to także stulecie przełamywania lęku i bezradności wobec sił przyrody (postęp techniczny, wynalazki). Szło za tym przekonanie, że relacje między ludźmi i społecznościami nie muszą być niezmienne, a ludzie coraz częściej w codziennym działaniu (niekoniecznie organizowanym na większą skalę) zaczynali dostrzegać możliwość panowania nad środowiskiem naturalnym. W taki oto sposób można było powoli umacniać zaufanie do człowieka i jego myśli. Działalność na rzecz realizacji woli Boga i myślenie nadal w kategoriach religijnych były niezbędnym elementem powstawania innego sposobu widzenia człowieka i świata. Stanowiły najprostszy wstępny krok do stopniowego podporządkowywania sobie przyrody na miarę możliwości XVII stulecia. Chodziło jednak również o środowisko społeczne. Zdaniem Christophera Hilla znalazło to wyraz w rozwoju wielu teorii myśli społecznej i w nowej tendencji do podkreślania praw społeczności niewywodzących się ze szlachty ${ }^{4}$.

Wyznawcy kalwinizmu przyczynili się również pośrednio do zmiany podejścia do nauki, odzierając ją ze średniowiecznej tajemniczości (choć był to dopiero początek tego procesu). Nauka według nich ma służyć do działań praktycznych, a nie kontemplacji.

${ }^{3}$ Ch. Hill, Oliver Cromwell, s. 228. Problem ten poruszany jest szeroko też w innych opracowaniach tego autora. Por. idem, Society and Puritanism in Pre-Revolutionary England, London 1991, s. 429-466; idem, The Intellectual Origins of the English Revolution. Revisited, Oxford 1997, s. 15-76; idem, Puritanism and Revolution. Studies in Interpretation of the English Revolution of the 17th Century, London 2001, s. $112-138$.

${ }^{4}$ Ch. Hill, Oliver Cromwell, s. 228-229. 
Chęć poznania Bożych celów skłaniała ludzi do zajmowania się naukami przyrodniczymi i historią̧. To, co jeszcze w połowie XVII w. czy w latach sześćdziesiątych tego stulecia było immanentnie związane z patrzeniem na świat w kategoriach teologicznych lub wąsko-praktycznych, z wolna, w perspektywie kilku dziesięcioleci wyzbywało się wszechobecności pierwiastka religijnego (choć nie negowało go całkowicie), wysuwając na plan pierwszy wnioski wypływające z trzeźwego oglądu świata i refleksji dotyczącej praw nim rządzących. Myśl społeczna, filozofia, sposób myślenia o polityce powoli, ale wyraźnie się zmieniały. Wydawałoby się, że debata w łonie elity intelektualnej toczyła się według dawnych reguł, ale były to pozory, gdyż jej klimat był inny. Coraz bardziej wykraczała ona poza dotychczasowe ramy, gdyż była atrakcyjna i interesująca dla większego niż dotychczas grona ludzi skłonnych do myślenia o swym miejscu w świecie, o państwie i religii. Było to zresztą zjawisko charakterystyczne dla rzeczywistości nie tylko Wysp Brytyjskich, ale i innych krajów europejskich, przeważnie protestanckich.

Ludzie ci stopniowo „windowali się” o własnych siłach w górę - nie tylko gospodarczo, ale również umysłowo i moralnie. Prowadziło to do przezwyciężania bierności i uznawania status quo we wszystkich obszarach działania i myśli. Wiodło to do (zrazu nieśmiałej) negacji poglądu, że Wszechświat i jego prawa są niezmienne, niepoznawalne i niezrozumiałe, a każda działalność - naukowa czy polityczna, zmierzająca do zmiany istniejących stosunków - jest bezsensowna. Jest oczywiście dyskusyjne, czy musimy widzieć działalność angielskich radykałów XVII w. tylko jako reakcję na „społeczne tło stagnacji gospodarczej, nierówności społecznej [lepiej powiedzmy społecznych podziałów - A.L.-L.] oraz tyranii religijnej i politycznej”' ${ }^{3}$. Wielu postaw nie można tak prosto wytłumaczyć, ale można zobaczyć z pewnej perspektywy skutki działań religijnych nonkonformistów w starciu z politycznym i religijnym establishmentem. Starcie to trwało długo i sięgnęło połowy XVII w., choć później temperatura sporów bardzo się obniżyła. Nowością w ich przesłaniu było położenie nacisku na pogląd, że Boga trzeba postrzegać jako swego rodzaju prawo i że Wszechświat jest rozumnie urządzony. Łączyło się z tym przekonanie, że ludzie żyją w świecie przeżywającym zmiany, a Bóg działa przez nich, aby przeprowadzić swe zamiary. Według Georga Hakewilla i Francisa Bacona najważniejsze było działanie człowieka rozumiane jako próba odkrywania świata po to, aby go zmienić. Podkreślali więc, a podzielali to przekonanie inni pisarze okresu wojny domowej i wczesnej restauracji w Anglii, że Wszechświat działa zgodnie z pewnymi prawami, co

ułatwiało powolne usuwanie magii z życia codziennego: cuda pozostawiono jedynie czasom początków Kościoła. Utorowało to drogę Newtonowskiej koncepcji Boga jako wielkiego

\footnotetext{
5 Ibidem, s. 229-230.

${ }^{6}$ Ibidem, s. 230.
} 
zegarmistrza, w myśl której wszechświat został na początku wprawiony w ruch przez siłę zewnętrzną, lecz odtąd porusza się własną siłą rozpędu?

Skutkiem tej postawy jest przekonanie o konieczności przezwyciężenia status quo.

Dla Newtona - matematyka, ale przecież i teologa - świat jest jednak w jakiś sposób statyczny. Odzwierciedla to sposób myślenia będący świadectwem epoki, która nastąpiła po rewolucji i restauracji Stuartów, a którą nazywam roboczo „epoką porządkowania rzeczywistości”. Można ją również określić jako cywilizację porewolucyjną ${ }^{8}$, choć jest to określenie chyba nieco na wyrost. W każdym razie istotne w przedstawionym sposobie myślenia kalwińskich teologów jest położenie nacisku na osobisty stosunek człowieka do Boga i koncepcję tego drugiego jako uosobienia prawa, porządku i celowości, postawienie przed człowiekiem zadania zrozumienia Bożych celów oraz współpracy w ich urzeczywistnianiu. Akceptacja tych poglądów sprzyjała trzeźwemu spojrzeniu na siebie, rzeczy i sprawy dziejące się wokół. Był to swego rodzaju empiryzm na miarę doświadczeń człowieka żyjącego i działającego w realiach siedemnastowiecznej Anglii i Szkocji. Bardziej zrozumiała jest wobec tego koncepcja Izaaka Newtona, która - choć można ją tłumaczyć przyjmowaniem kalwińskiej teologii - zdaje się statycznym obrazem świata stworzonym przez ludzi działających i współtworzących przesłanki cywilizacji okresu porewolucyjnego w Anglii, który zapowiadał zjawisko nazwane później wczesnym Oświeceniem. John Bunyan widział przecież jeszcze w Bogu „pogodzenie najbardziej doniosłych sprzeczności” 9 . Bóg był więc „potrzebny do wprowadzenia zmienności $\mathrm{w}$ to, co by w przeciwnym razie było statycznym, mechanistycznym wszechświatem"10. Otwierało to nowe perspektywy przed szeroko pojętymi naukami przyrodniczymi, ułatwiając choćby usuwanie barier przed eksperymentem i ocenę jego znaczenia z punktu widzenia rozwoju nauki. W tym zakresie Wyspy Brytyjskie i Zjednoczone Prowincje Niderlandów Północnych rychło zaczęły dzierżyć prymat w nauce europejskiej (szerzej - strefy cywilizacji euroatlantyckiej).

Dla angielskich i szkockich radykalnych kalwinistów powyższa postawa była istotna także dlatego, że łączyła się z postrzeganiem dziejów ludzkości jako „racjonalnego ciągu zdarzeń ujawniającego intencje Boga”. Oliver Cromwell twierdził, że

ważne jest jedynie to w czym tkwi życie i moc historii: owe gwałtowne zakręty i zwroty Opatrzności, owe wspaniałe objawienie się Boga poprzez udaremnienie i zniweczenie dążeń ludzkich [...] przy użyciu środków całkiem nieoczekiwanych, zasługujących pozornie na zupełne lekceważenie ${ }^{11}$.

\footnotetext{
7 Ibidem, s. 231.

${ }^{8}$ Ibidem. Por. również J. Kierul, Newton, Warszawa 2010.

9 Ch. Hill, Oliver Cromwell, s. 232.

${ }^{10}$ Ibidem.

${ }^{11}$ Ibidem.
} 
Nie wierzmy więc w przypadki - nie ma zbiegów okoliczności, a jeśli tak się nam wydaje, to tylko dlatego, że nie potrafimy odczytać planów Boga.

Historia staje się powoli domeną ludzkiego rozumu. Musiało jeszcze upłynąć kilka dekad, zanim tego rodzaju poglądy zaczęły być akceptowane w wąskich kręgach intelektualistów, by później w epoce dojrzałego Oświecenia na dobre wśród nich zagościć, ale to już perspektywa połowy XVIII stulecia. Droga do pewnych zjawisk charakterystycznych dla cywilizacji przemysłowej otwierała się w postaci wąskiej ścieżki wiodącej uczonych i teoretyków myśli społecznej ku nowym perspektywom badawczym, otwierającym wrota do nowej cywilizacji, w której tak wielką rolę mieli odegrać naukowcy i wynalazcy. Nie oznaczało to kresu inspiracji teologicznej w wielu poszukiwaniach nowych dróg, ale specyficzny mariaż religii (czy raczej teologii) i nauki w ówczesnym jej rozumieniu stwarzał przesłanki cywilizacji, w której zdobycze nauki uzyskiwały akceptację. Dominacja intelektu nad uczuciem i światem kształtów i barw, czyli - jak to celnie wyraził Emanuel Mateusz Rostworowski - światem wartości akceptowanym przez Europę katolicką, która nadała określony kształt Oświeceniu angielskiemu, była skutkiem tego, że tzw. angielska i szkocka rewolucja XVII w. w Kościele i państwie walczyła o religię, wolność i własność - wartości już istniejące lub za takie uważane. Ale odwołanie się do dawnych czasów oznaczało co innego dla różnych jednostek czy grup społecznych. Ta rozbieżność opinii sprzyjała odrzucaniu wiedzy „o ludziach i rzeczach"12, co stwarzało nowe perspektywy poznawcze prowadzące do deizmu ${ }^{13}$.

Wszystkie wspomniane wyżej zjawiska oddziaływały na sposoby postrzegania otoczenia, mechanizmy opisywania rzeczywistego i urojonego świata, pogłębiały jego rozpoznawanie. Nie oznaczało to całkowitego odrzucania religii, w każdym razie w angielskiej rzeczywistości. Zapowiadało za to nową perspektywę w wielu dziedzinach życia, poprzedzającą przewrót umysłowy. Opisane postawy wpływały również na rozwój starych i powstawanie nowych, dojrzalszych form wypowiedzi literackich - począwszy od angielskiej powieści realistycznej i jej przedstawiciela Daniela Defoe, który zanim zamknięto go w XIX w. w czterech ścianach dziecinnego pokoju, stał się prekursorem nowych horyzontów wrażliwości literackiej Europejczyków, do powieści sentymentalnej połowy XVIII stulecia ${ }^{14}$.

Dorzućmy jeszcze rodzącą się na Wyspach Brytyjskich od czasów Wilhelma i Marii sztukę żywiącą się innymi niż poprzednio treściami, bardziej indywidualną, nieulegającą obcym wpływom (może z wyjątkiem Zjednoczonych Prowincji), szczególnie w sposobie traktowania krajobrazu i studiach postaci, starającą się uchwycić charakterystyczny, niepowtarzalny wyraz twarzy, gestu, kontekst społeczny i obyczajowy

12 E. Rostworowski, Historia powszechna. Wiek XVIII, Warszawa 1977, s. 416; Ch. Hill, Oliver Cromwell, s. $201 \mathrm{in}$.

13 E. Rostworowski, Historia powszechna, s. 425-426.

${ }_{14}$ I. Watt, Narodziny powieści. Studia o Defoe'em, Richardsonie i Fieldingu, Warszawa 1973. 
właściwy epoce, wreszcie - co najbardziej zauważalne u Williama Hogartha - zawrzeć satyrę i szyderstwo z ludzkich przywar ${ }^{15}$. Ważną nowością i świadectwem coraz większego zainteresowania tak pojmowanymi założeniami było zjawisko powstawania kameralnych, bardzo „osobistych” portretów kobiet, jak choćby portret królowej Karoliny pędzla Thomasa Gainsborough („Queen Charlotte”, September 1782, Royal Collection). Coraz częściej powstawały dzieła, będące świadectwem uprawiania sztuki dla przyjemności ${ }^{16}$, co spotykało się później z krytyką tych, którzy przypisywali sztuce przede wszystkim dydaktyzm, konieczność dążenia do wzbudzenia u odbiorcy określonych, pozytywnych uczuć, służących moralnemu doskonaleniu.

Było to jednak zjawisko charakterystyczne bardziej dla „południa wieku Oświecenia” niż dla epoki wcześniejszej. Lekkość i frywolność schyłkowego baroku i rokoka odchodziły z wolna w zakamarki wykwintnych rezydencji i salonów, zarówno w Wielkiej Brytanii, jak i na kontynencie. Były to już jednak inne czasy.

Warto ponadto wspomnieć o problemie roli kultury popularnej i jej zapożyczeń z kultury „wysokiej” w przejściowej epoce, którą najogólniej można określić „między barokiem a Oświeceniem”. To zjawisko oczywiste, bardzo trudno uchwytne, choć ważne z punktu widzenia „osmozy” pewnych wartości odrębnych czy wspólnych, niezależnie od oczywistych różnic klasowych. Bogactwo i przemiany form stylistycznych dotyczyły przecież także kultury, ale na razie wypadnie się ograniczyć do stwierdzenia, że Oświecenie w krajach katolickich odwoływało się do nieco innych wartości niż świat protestancki, który zainicjował wielki przełom umysłowy i stworzył płaszczyznę intelektualną, na której poruszali się później wszyscy ludzie zaangażowani w przemianę istniejącego świata, dominował w zakresie konstrukcji myślowych. Znajdowało to odzwierciedlenie w twórczości artystycznej i produkcji rzemieślniczej. Innymi słowy, był to świat, w którym cywilizacja ołtarza zderzała się coraz częściej z cywilizacją lektury Pisma Świętego i wynikających stąd wniosków. Nawiasem mówiąc, nie zawsze prowadziło to do wojującego czy wręcz prymitywnego ateizmu, jak możemy się o tym dowiedzieć z przekazów płynących dziś z niektórych ambon. Oświecenie ma przecież także oblicze chrześcijańskie czy wręcz katolickie.

Natomiast odrębną kwestią jest, na ile pożegnanie, czy raczej stopniowe żegnanie się ze światem starych wartości, wywoływało uczucie nostalgii i żalu. Na pewno nieraz tak było. Może w najbardziej widoczny, a jednocześnie syntetyczny sposób potrafiła to przedstawić sztuka, choć podobnie jak w przypadku nauki, nie wszystkie dokonania i ich twórcy prostą drogą i bez wahań wkraczali na nowe szlaki. Analogicznie jak w sztuce, nie istniała jedna, „właściwa” linia rozwoju nauki, która prowadziła do

15 R. Paulson, William Hogarth, Warszawa 1984; dawna praca A. Potockiego, Portret i krajobraz angielski, Lwów 1907, Nauka i Sztuka, t. VI - warto po nią sięgnąć z uwagi na liczne ilustracje. Por. również K. Piwocki, Dzieje sztuki w zarysie. Od wieków średnich do końca XVIII w., Warszawa 1977, s. 286-294.

16 J. Black, Europa XVIII wieku 1700-1789, Warszawa 1997, s. 303. 
dziewiętnastowiecznego czy współczesnego rozumienia istoty badań naukowych ${ }^{17}$. Gdy idzie o naukę, nawet teorie, których doświadczenie nie zweryfikowało mogły prowadzić do postępu badań. Jednakże podstawowe znaczenie w dokonującej się coraz śmielej i mającej co najmniej siedemnastowieczną metrykę rewolucji naukowej było przekonanie, że "dzięki rozumowaniu i badaniom empirycznym” człowiek może zrozumieć (czy próbować zrozumieć) prawa rządzące jego własnym życiem oraz otaczającym go światem. Ponieważ jednak poznanie naukowe przypominało bardziej proces niż odkrywanie ostatecznych prawd, wiara w możliwości ludzkiego poznania sprzyjała nie tylko uznaniu dla działalności wielu szarlatanów i pseudouczonych, ale także ciągłemu przenikaniu się metafizyki, teologii, zainteresowania człowiekiem oraz nauką i eksperymentami - zjawiskom, które były tak ważne w XVII stuleciu i przygotowywały epokę nazwaną później wczesnym Oświeceniem ${ }^{18}$. Był to zatem świat bliski angielskim i szkockim uczonym i teologom XVII w.

Postęp dokonywał się więc krętymi drogami, które rozpoznajemy z trudem, znając głównie opinie oświeconych elit, zamazujące czasem rzeczywistość, ustępującą pod naporem wyznawców całkiem nowego opisywania świata, którzy zresztą opisywali go, nie będąc wolnymi od powracających prób cofania się i błędów. Postęp był jednak widoczny we wszystkich sferach myśli, choć jeszcze Jean-Paul Marat, publikując prace na temat ciepła, światła i elektryczności twierdził, że „odkrył fluidy nerwowe, optyczne, ogniowe i elektryczne" oraz odrzucał teorie Newtona, a Nicolas-Philippe Ledru, założyciel paryskiej, swego rodzaju kliniki psychiatrycznej, w której leczył elektrowstrząsami w latach osiemdziesiątych lekarz Ludwika XVI, „interesował się przepowiadaniem przyszłości" ${ }^{\prime 1}$. Zresztą sam Newton dowodzil, że Bóg interweniuje, by utrzymać ciała niebieskie na swoich miejscach. Nauka, mimo jej osiągnięć, współegzystowała z wiarą, że własne winy albo wrogie intencje innych ludzi mogą powodować nieszczęśliwe wypadki. Oczywiście dotyczyło to szczególnie medycyny, w przypadku której postęp w badaniach musiał zmagać się z niewiedzą, ekscytacją seksualną oraz potępieniem grzechu ${ }^{20}$. Ważna była nadal tradycja, ale zdobycze nauki były coraz częściej akceptowane, zrazu przez wąskie kręgi uczonych i entuzjastów wiedzy. Już John Locke twierdził, że cała wiedza składa się z idei będących pochodnymi wrażeń. Jednak eksperymenty, nawet prowadzące do nieuzasadnionych wniosków, były odzwierciedleniem dążenia do wykroczenia poza dotychczasową wiedzę $e^{21}$ W osiemnastowiecznej Anglii powstał rynek podręczników i prac popularnych przeznaczonych m.in. dla kobiet i dzieci ${ }^{22}$. Było to całkowicie nowe zjawisko.

\footnotetext{
17 J. Black, Europa, s. 322.

18 Ibidem.

19 Ibidem, s. 323-324.

20 Ibidem, s. 324.

21 Ibidem, s. 325.

22 Ibidem, s. 332.
} 
Powiedzmy więc na koniec, że kultura oświeceniowych elit miała nadal charakter przede wszystkim chrześcijański, a nowe prądy akcentowały głównie znaczenie uczuć i wrażliwości w sztuce oraz literaturze, zainteresowanie Starożytnością, odległymi ludami, kontynentami i kulturami. Podkreślają to właściwie wszyscy współcześni znawcy epoki ${ }^{23}$. Warto ponadto wspomnieć o swoistej „gęstości” sztuki tego okresu, która operowała środkami odwołującymi się do swobodnej, nieokiełznanej wyobraźni, potrafiła pokazać uczucia w ich zmysłowym napięciu, wznieść się ponad wymiar ckliwej anegdoty. Człowiek w tej sztuce staje się samotny wobec Wszechświata.

Spójrzmy na obraz Josepha Wrighta of Derby pt. Eksperyment z ptakiem w pompie powietrznej (zwany też Doświadczenie z pompa próżniowa) z Tate Britain w Londynie - namalowaną u schyłku angielskiego Oświecenia (1768) swego rodzaju ikonę, zawierającą syntezę, nazwijmy to nieprecyzyjnie, „oświeceniowego” malarstwa, dzieło na pograniczu sceny rodzajowej i alegorii. Światło technicznej wiedzy objawianej przez eksperymentatora, wywołujące zresztą skojarzenia religijne, ma spływać na skupionych wokół niego obserwatorów. Moment ten wywołuje różne reakcje, w zależności od wieku patrzących. Doświadczenie - tortura dla ptaka zamkniętego w pompie może być źródłem cierpienia dla patrzących na nie dzieci. To alegoria człowieka - istoty poszukującej, zanurzonej w materii świata, emocjonalnie reagującej ${ }^{24}$.

Uchwycenie dramaturgii ludzkiego losu, przedstawienie człowieka szamoczącego się w pajęczynie swych nawyków, doświadczeń, uprzedzeń, myśli, ale przede wszystkim pokazanie nowej materii i perspektyw codzienności, właściwe jedynie sztuce i wrażliwości artysty (niezwykle rzadko cechujące tzw. uczoność), to - do dziś atrakcyjne poznawczo - jedno z najważniejszych przesłań Oświecenia, epoki, która stworzyła nowoczesnego Europejczyka. Jednocześnie raz jeszcze podkreślam, że narodziny tego nurtu w dziejach cywilizacji europejskiej sięgają Anglii pierwszych dekad XVII w. i Niderlandów, a religijna inspiracja jest w ogromnej części oświeceniowej myśli niesłychanie silna, choć na Wyspach Brytyjskich punktem wyjścia wielu dociekań był intelekt poszukujący praw rządzących światem. W myśli francuskiej XVIII w. dominowały natomiast raczej szersze koncepcje czy modele, czasem utopijne, czasem zbyt radykalne, by mogły szybko zmienić społeczną rzeczywistość ${ }^{25}$.

23 Ibidem, s. 298.

24 A. Pieńkos, Między prymitywizmem a kulturą. Wizje cierpienia w malarstwie XVIII wieku, "Znak” 1992, R. XLIV, nr 451, Dziedzictwo Oświecenia, s. 95.

25 Por. J.I. Israel, Radical Enlightenment: Philosophy and the Making of Modernity 1650-1750, Oxford 2001, s. 212-214. Dziękuję Panu Doktorowi Piotrowi Robakowi za inspirującą dyskusję, która pozwoliła mi przemyśleć niektóre kwestie poruszone w artykule. 


\begin{abstract}
The Author is trying to explain the "English" or "British" background of the Enlightenment by showing two main elements of the first shape of Pre-Enlightenment attitudes in the $17^{\text {th }}$ century. Most important were the tracts of the Calvinists and radical nonconformists (Puritans). They stressed importance of the human-free will and experiment in opposition to the God's intervention in the history of the mankind.
\end{abstract}

\title{
Keywords
}

Enlightenment, Calvinism, Puritanism. 